\title{
Manajemen Resiko dalam Perpajakan
}

\author{
Arna Suryani \\ Fakultas Universitas Batanghari \\ Correspondence email: arna_halim@yahoo.co.id
}

\begin{abstract}
Abstrak. Penelitian ini bertujuan untuk mengetahui dan menganalisis bagaimana pengelolaan manajemen resiko serta apa saja resiko perpajakan yang dapat timbul sehingga perlu dilakukan manajemen resiko dalam perpajakan. Metode penelitian yang digunakan adalah metode penelitian kajian pustaka dengan mengkaji mengenai konsep dan teori yang digunakan berdasarkan literatur yang tersedia terutama artikel-artikel yang dipublikasi dalam berbagai jurnal ilmiah. Manajemen resiko yang baik akan meminimalkan kerugian-kerugian yang dihadapi perusahaan, sehingga perusahaan bisa tetap menjaga kelangsungan hidupnya bahkan bisa berkembang menjadi perusahaan yang besar dan sukses dalam bisnisnya. Manajemen resiko perpajakan penting dilakukan oleh setiap perusahaan, agar setiap perusahaan dapat mengelola resiko pajak dengan baik dan dapat mengurangi dampak negatif dari resiko yang dialami perusahaan. Dalam memenuhi kewajiban pajak, perusahaan perlu melakukan pemotongan atau pemungutan, penyetoran dan pelaporan yang semuanya itu harus mengikuti peraturan perpajakan yang berlaku. Manajemen resiko perpajakan yang berhasil hanya dapat dicapai perusahaan dengan memiliki kerangka kerja pengendalian resiko pajak yang kuat, baik dari sisi internal maupun ekternal.
\end{abstract}

Kata Kunci: Manajemen Perpajakan, Manajemen Resiko perpajakan, Manajemen resiko, Resiko

\begin{abstract}
This research aims to identify and analyze how risk management is and what tax risks can arise, so it is necessary to carry out risk management in taxation. The research method used is literature review research method by examining the concepts and theories used based on the available literature, especially articles published in various scientific journals. Good risk management will minimize the losses faced by the company, so that the company can maintain its survival and can even develop into a large and successful company in its business. Tax risk management is important for every company, so that each company can manage tax risk properly and can reduce the negative impact of risks experienced by the company. In fulfilling tax obligations, companies need to deduct or collect, deposit and report all of which must comply with applicable tax regulations. Successful tax risk management can only be achieved by companies with a strong tax risk control framework, both internally and externally.
\end{abstract}

Keywords: Risk, Risk Management, Tax Risk, Tax Risk Management.

\section{Pendahuluan}

Resiko merupakan hal yang selalu ada pada perusahaan yang sedang berjalan. Cara meminimalkan resiko yang muncul yaitu perusahaan harus bisa mengatur kinerja perusahan agar tidak mengganggu proses kinerja perusahaan. Pengaturan ini yang disebut dengan istilah manajemen resiko. Manajemen resiko diartikan sebagai suatu proses analisis, identifikasi, penilaian, pengendalian, dan upaya menghindari, meminimalisir, atau bahkan menghapus resiko yang tidak dapat diterima (Michel Crouchy dan Galai \& Robert Mark, 2000). Sedangkan definisi menurut perusahaan adalah suatu proses pengaturan, perencanaan pengontrolan dan pemimpinan aktivitas suatu organisasi untuk meminimal resiko pendapatan perusahaan. Manajemen Resiko selama ini lebih dikenal dalam industri perbankan, Bank Nasional harus menerapkan manajemen resiko terhitung yang wajib dilaksanakan sesuai jadwal yang dikemukakan dalam action plan atau paling lambat 31 Desember 2004 yang bertujuan mengurangi resiko perbankan nasional "sesuai Surat Edaran BI No 5/21/DPNP tanggal 29 September 2003, Bank Indonesia (BI)".

Perpajakan nasional apakah belum menerapkan Manajemen resiko? jika belum, sekarang saat yang tepat untuk melakukannya. Mengelola kewajiban pajak menjadi suatu hal penting dalam menjalankan bisnis, terutama ketika mempertimbangkan dampak internal dan eksternal dari strategi investasi agar dapat menghasilkan struktur pajak yang efektif. Untuk menghindari potensi-potensi kerugian yang disebabkan oleh perpajakan, maka diperlukan pengendalian terhadap resiko yang timbul dari perpajakan atau upaya untuk memitigasi resiko yang terjadi dalam perpajakan yang dikenal dengan manajemen resiko perpajakan. Manajemen resiko perpajakan adalah upaya pelaku usaha dalam memitigasi resiko yang terjadi ketika tidak sanggup melapor atau membayar pajak kepada Direktorat Jendral Pajak (DJP) sehingga mengakibatkan adanya pemberian saksi administrasi atau sengketa pajak. Manajemen resiko perpajakan yang baik dalam suatu usaha dapat menciptakan suatu nilai tambah bagi perusahaan, hal ini diasumsikan perusahaan mampu mengidentifikasi dan mengatasi atas resiko yang terjadi dalam perusahaan.

Manajemen Resiko perpajakan yang berhasil hanya dapat dicapai perusahaan dengan memiliki kerangka kerja pengendalian resiko pajak yang kuat, baik dari sisi internal maupun ekternal. Dari sisi eksternal, perusahaan harus melakukan pelaporan perpajakan yang efektif dan konsisten, termasuk terkait transfer harga, pelaporan keuangan dan keterbukaan kepada publik. Sementara dari sisi internal pelaku usaha harus memiliki strategi dan tata kelola pajak, 
memiliki kerangka kerja proses pengendalian sumber daya manusia dan sistem perpajakan untuk mendukung kepatuhan bisnis yang efektif, yang pada akhirnya akan memberikan jaminan perpajakan. Berdasarkan uraian yang telah dijelaskan di atas maka penelitian ini bertujuan untuk mengetahui bagaimana tahapan dalam pengelolaan resiko, dan apa saja resiko perpajakan yang dapat timbul sehingga perlu dilakukan manajemen pengelolaan resiko dalam perpajakan.

\section{Kajian Literature \\ Resiko}

Istilah resiko dalam pembicaraan sehari-hari sudah tidak asing lagi bagi kebayakan orang. Bagi pembuat keputusan pengertian resiko telah didiskusikan untuk membuat suatu arti resiko yang sesuai untuk dianalisis demi kepentingan masing-masing. Resiko merupakan suatu kondisi yang mengarahkan kepada sekumpulan hasil khusus, dimana hasilnya dapat diperoleh dengan kemungkinan yang telah diketahui oleh para pengambil keputusan ( Irham Fahmi, 2010). Karena banyaknya bidang kegiatan yang berbeda beda walaupun dengan menggunakan fasilitas yang sama, hal ini yang menyebabkan sampai saat ini para pembuat ketupusan tersebut belum bersepakat untuk menggunakan satu definisi resiko saja. Oleh sebab itu, dengan memahami dan mempelajari definisi yang telah ditemukan diberbagai literatur dapat memanambah pemahaman tetang konsep resiko. Dalam Peraturan Menteri Keuangan No 191/PMK.09/2008 menyatakan bahwa resiko merupakan segala sesuatu yang bisa berdampak negatif terhadap pencapaian tujuan yang di ukur dengan kemungkinan dan dampaknya. Resiko merupakan kondisi yang dihubungkan dengan kemungkinan terjadinya hal yang tidak diharapkan sehingga menyebabkan kerugian atau akibat yang tidak diinginkan. Adanya ketidakpastian resiko menunjukkan kondisi yang dapat menyebabkan munculnya kemungkinan kerugian dari hal-hal yang tidak diharapkan.

\section{Manajemen Resiko}

Manajemen Resiko merupakan suatu usaha untuk mengetahui, menganalisis serta mengendalikan resiko dalam setiap kegiatan perusahaan dengan tujuan untuk memperoleh efektifitas dan efisiensi yang lebih tinggi (Michel Crouchy dan Galai \& Robert Mark (2000). Sedangkan dalam Australia/New Zealand Standards (1999) menyatakan bahwa suatu proses yang masuk akal dan sistematis dalam menganalisa, mengidentifikasi, mengevaluasi, mengawasi, mengendalikan dan mengkomunikasikan resiko yang berhubungan dengan segala aktifitas, fungsi atau proses dengan tujuan perusahaan mampu meminimalkan kerugian dan memaksimumkan kesempatan. Bagi suatu perusaaan Manajemen Resiko terintegrasi dengan seluruh organ perusahaan, oleh sebab itu perusahaan harus dapat membangun atau membentuk budaya pengelolan resiko dengan baik. Pengelolaan manajemen resiko yang baik perlu adanya suatu pengendalian resiko oleh perusahaan. Pengendalian resiko dalam suatu perusahaan dimulai dengan adanya suatu perencanaan manajemen resiko bertujuan untuk mengidentifikasi resiko, kejadian yang mungkin akan muncul sehingga dapat mempengaruhi keinginan tujuan Perusahaan. Bagi suatu Perusahaan jika dalam pengelolaan resiko dilakukan dengan keinginan dan toleransi perusahaan yang berlaku, tentunya hal ini kemungkinan memberikan kepastian atau keyakinan pada pencapaian tujuan perusahaan tersebut.

\section{Manajemen Perpajakan}

Manajemen perpajakan merupakan suatu kegiatan mewujudkan fungsi manajemen sehingga efisiensi serta efektifitas dalam pelaksanaan hak dan kewajiban perpajakan dapat tercapai. (Bernard, 2011) menyatakan bahwa Manajemen perpajakan akan bermanfaat atau memiliki nilai guna yang besar apabila perusahaan tersebut dapat melaksanakan sesuatu dengan tujuan awal yang telah diterapkan. Meminimalkan beban pajak seminimum mungkin dilakukan dengan menekan penghasilan-penghasilan atau memperbesar biaya-biaya yang bisa dikurangkan dari penghasilan sehingga penghasilan pajak akan lebih kecil atau memanfaatkan hal-hal yang belum diatur dalam peraturan perpajakan merupakan strategi mengefektifkan beban pajak atau penghematan pajak yang dilakukan oleh perusahaan juga harus bersifat legal, untuk dapat menghindari sanksi-sanksi pajak di masa akan datang. Biasanya Penghematan Pajak menganut prinsip the last and lates yaitu dengan membayar dalam jumlah yang sekecil mungkin dengan waktu terakhir yang masih diizinkan dalam peraturan pajak dan Undang-undang. Suandy (2011) menyatakan bahwa tujuan dari manajemen pajak dapat dicapai melalui fungi-fungsi manajemen pajak yang terdiri dari Perencanaan Pajak, Pelaksanaan Kewajiban Pajak dan Pengendalian Pajak.

\section{Manajemen Resiko Perpajakan}

Aspek Perpajakan tidak hanya berdampak pada resiko keuangan tetapi bisa meluas menjadi resiko reputasi, resiko operasional serta resiko bisnis jika pada akhirnya tidak dilakukannya pengendalian manajemen resiko dengan optimalkan akan terdapat dampak serius terhadap keberlansungan usaha/hidup perusahaan. Perusahaan harus dapat melakukan pengelolaan resiko perpajakan dengan baik dengan cara mitigasi untuk menghindari atau mengurangi dampak yang timbul dari perpajakan untuk mencapai tujuan perusahaan. 


\section{Metode}

Pada penlitian ini metode yang digunakan adalah metode studi pustakaan dan kajian pustaka dengan menerapkan kajian tentang teori-teori yang relevan dengan masalah penelitian serta penelitian ini juga melakukan kajian mengenai konsep dari teori yang digunakan berdasarkan literature yang ada, teruntuk artikel yang dipublikasikan dalam berbagai jurnal ilmiah. Kajian pustaka ini digunakan untuk membangun teori atau konsep yang mendasari studi dalam penelitian ini (Sujarweni, 2014). Kajian pustaka atau sering disebut dengan studi pustaka merupakan kegiatan yang harus ada dalam penelitian terkhusus pada penelitian akademik dengan tujuan utamanya untuk mengembangkan aspek teoritis maupun aspek manfaat praktis (Sukardi, 2013). Berdasarkan metode penelitian tersebut dapat mempermudah peneliti untuk menyelesaikan masalah yang ingin di teliti.

\section{Hasil}

Resiko membuktikan adanya ketidakpastian dalam kondisi yang menyebabkan tumbuhnya kemungkinan kerugian dari hal-hal yang tidak diharapkan. Oleh sebab itu perusahaan harus mengendalikan resiko dalam suatu pengelolaan manajemen resiko yang baik. Bagi suatu perusaaan manajemen resiko berkaitan dengan seluruh organ yang ada pada perusahaan, diharapkan perusahaan harus bisa membangun atau membentuk budaya pengelolan resiko dengan baik. Pengelolaan manajemen resiko yang baik perlu adanya suatu pengendalian resiko oleh perusahaan. Pengendalian resiko dalam suatu perusahaan dimulai dengan adanya suatu perencanaan manajemen resiko yang bertujuan untuk mengidentifikasi resiko yang potensial yang muncul sehingga bisa mempengaruhi tujuan yang ingin di capai oleh perusahaan.

Bagi suatu perusahaan dalam pengelolaan resiko dilakukan kesesuaian terhadap keinginan dan toleransi perusahaan dengan demikian hal ini dapat memberikan kepastian dan keyakinan terhadap pencapaian tujuan perusahaan. Beberapa tahapan dalam pengelolaan resiko dapat dilakukan dengan cara sebagai berikut.

1. Penetapan Konteks, tujuan dari Penetapan Konteks yaitu dalam hal menganalisis serta mengidentifikasi serta untuk mengevaluasi resiko. Pada penetapan kontek terlebih dahulu menentukan pihak mana yang memiliki kepentingan dengan penerapan manajemen resiko. Setelah itu menentukan tujuan proses, ruang lingkup, kondisi yang membatasi serta hasil yang diharapkan dari penerapan manajemne resiko yaitu dengan melakukan penyusunan kriteria untuk menganalisis dan mengevaluasi resiko tersebut.

2. Identifikasi Resiko, tujuan dari Identifikasi Resiko yaitu mengidentifikasi keseluruh jenis resiko yang memiliki potensi menurunkan, menghalangi, atau menunda tercapainya sasaran unit pemilik resiko. Dengan mengidentifikasi waktu, lokasi, sebab dan proses terjadinya resiko yang mempengaruhi penundaan terwujudnya keinginan yang ditentukan merupakan proses dari Identifikasi Resiko.

3. Analisis Resiko, tujuan dari Analisis Resiko yaitu mengetahui peta dan profil keseluruhan resiko yang terdapat di perusahaan untuk proses ecaluasi serta strategi penanganan resiko. Dengan mencermati sumber dari resiko dan tingkat pengendalian resiko serta dengan menilai resiko dari konsekuensi dan kemungkinan terjadinya merupakan proses dari Analisis Resiko.

4. Evaluasi Resiko, tujuan dari Evaluasi resiko yaitu menetapkan prioritas resiko yang telah diidentifikasi dan dianalisis. Para pengambil keputusan dalam mempertimbangkan perlu atau tidaknya dilakukan penanganan resiko lebih lanjut serta prioritas penanganannya terhadap hal tersebut merupakan proses dari Evaluasi Resiko.

5. Penanganan Resiko, tujuan dari Penanganan resiko yaitu dalam menentukan jenis penanganan yang efektif dan efisien. Dengan mengidentifikasi berbagai opsi penanganan resiko yang tersedia dan memutuskan opsi penanganan resiko yang terbaik kemudian dilanjutkan dengan pengembangan rencana mitigasi resiko merupakan proses dari Penanganan Resiko

6. Monitoring dan Review, tujuan dari Monitoring dan review yaitu mengantisipasi perubahan resiko yang mendadak dan persistent baik pada tingkat resiko maupun arah resiko sehingga berdampak negatif pada profil resiko. Dengan memantau efektivitas rencana penanganan resiko, strategi, dan sistem manajemen resiko merupakan proses dari Monitoring dan review.

7. Komunikasi dan Konsultasi, tujuan dari Proses komunikasi dan konsultasi yaitu memperoleh informasi yang relevan serta mengkomunikasikan setiap tahapan proses manajemen resiko kepada pihak-pihak yang terkait untuk menjalankan tanggung jawabnya dengan baik. Proses seluruh manajemen resiko ini dilakukan dengan cara mengembangkan komunikasi dengan stakeholder internal maupun eksternal.

Manajemen resiko perpajakan yang baik dalam suatu perusahaan dapat menciptakan added value bagi perusahaan, dikarenakan perusahaan mampu mengidentifikasi dan mengatasi atas resiko yang terjadi di dalam perusahaan. Suandy (2011) menyatakan bahwa tujuan dari manajemen pajak dibagi menjadi dua, yaitu pertama menerapkan peraturan perpajakan secara benar dan kedua menjalankan usaha efisiensi untuk mencapai laba dan likuidatas yang seharusnya dengan melalui fungsi manajemen pajak maka tujuan manajemen pajak dapat dicapai melalui: 
1. Tax Planning yaitu suatu langkah awal dalam Manajemen pajak. Pertama dengan melakukan Pengumpulan dan penelitian terhadap peraturan perpajakan dengan tujuan dapat menyeleksi jenis tindakan penghematan pajak yang akan dilakukan. Dalam hal meminimumkan kewajiban pajak serta dengan memanfaatkan peraturan yang ada tetapi berbeda dengan tujuan dari pembuat undang-undang merupakan tujuan dari penekanan tax planning. Ada beberapa hal yang perlu dierhatikan dalam membuat tax planning yaitu : pertama tidak melanggar kewajiban serta sesuai ketentuan perpajakan, kedua jika dilihat secara bisnsi perencanaan pajak harus yang masuk akal, dan yang ketiga memiliki bukti pendukung yang memadai.

2. Tax Implementation merupakan tahap untuk mengimplementasikan pajak baik secara formal maupun material. Pelaksanaan kewajiban perpajakan harus memenuhi peraturan perpajakan yang berlaku, dimana manajemen pajak yang dilakukan tidak dimaksudkan untuk melanggar peraturan. Ada dua hal yang perlu dikuasai dan dilaksanakan dalam mencapai tujuan Manajemen pajak yaitu pertama Memahami ketentuan dan peraturan perpajakan dilakukan agar kita dapat mengetahui peluang-peluang yang dapat dimanfaatkan untuk menghemat beban pajak, kedua menyelenggarakan pembukuan yang memenuhi syarat Pembukuan.

3. Tax Control, tujuan dari Tax Control atau pengendalian pajak yaitu memastikan bahwa kewajiban pajak telah dilaksanakan sesuai rencana dan telah memenuhi persayaratan formal maupun materil. Manajemen resiko perpajakan yang berhasil hanya dapat dicapai perusahaan dengan memiliki kerangka kerja pengendalian resiko pajak yang kuat, baik dari sisi internal maupun ekternal. Dari sisi eksternal, perusahaan harus melakukan pelaporan perpajakan yang efektif dan konsisten, termasuk terkait transfer harga, pelaporan keuangan dan keterbukaan kepada publik. Sementara dari sisi internal pelaku usaha harus memiliki strategi dan tata kelola pajak, memiliki kerangka kerja proses pengendalian sumber daya manusia dan sistem perpajakan untuk mendukung kepatuhan bisnis yang efektif, yang pada akhirnya akan memberikan jaminan perpajakan.

Pengelolaan resiko perpajakan yang optimal diharapkan dapat meningkatkan nilai perusahaan atau Upsize Risk dan juga dapat menghindari atau mengurangi semaksimal mungkin mungkin resiko yang timbul dan akan berdampak secara signifikan terhadap kelangsungan usaha perusahaan. Berbagai macam resiko perpajakan yang perlu menjadi perhatian bagi dunia usaha antara lain.

a. Resiko PPh Pasal 21, pada perusahaan resiko PPH 21 terjadi karena perusahaan memiliki kewajiban untuk memotong pajak karyawannya.

b. Resiko PPN, resiko yang timbul dari setiap transaksi penjualan dan pembelian dari barang kena pajak maupun jasa.

c. Resiko PPh Badan, setiap perusahaan memiliki resiko PPH Badan untuk membayar pajak penghasilan. Dimana pajak penghasilan dari perusahaan adalah pajak yang terkait dnegan transaksi perusahaan dan akuntansi secara keseluruhan, yaitu Penerimaan/pendapatan, Pembayaran beban operasional, Perhitungan penyusutan, Penjualan barang/jasa yang bukan aktivitas utama dan Laba/rugi usaha/selisih antara penerimaan dengan beban.

d. Resiko Pemotongan atau Pemungutan Pihak Ketiga

1. PPh Pasal 22 yaitu Bendaharawan: Tidak tepat waktu dan tercecer.

2. $\mathrm{PPh}$ Pasal 23: Kesalahan pemotongan dan tidak tepat waktu dan tercecer.

3. PPh Pasal 4 (2): Kesalahan pemotongan dan Tidak tepat waktu dan tercecer.

e. Resiko Pemeriksaan, wajib pajak yang meliputi Orang pribadi dan badan perusahaan memiliki resiko pemeriksaan karena sistem pajak di Indonesia menganut Self Assessment. Dimana sistem tersebut dapat menimbulkan kemungkinan sangketa pajak antara fiskus dan wajib pajak dan berujung pada pemeriksaan pajak.

f. Resiko Keberatan, pengajuan keberatan merupakan hak WP yang dapat dimanfaatkan untuk memperjuangkan keadilan, namun tetap mengandung resiko.

g. Resiko Banding, sama halnya dengan pengajuan keberatan, pengajuan banding merupakan hak Wajib Pajak yang dapat dimanfaatkan untuk memperjuangkan keadilan, namun demikian tetap mengandung resiko. Resiko yang melekat dalam pengajuan banding adalah apabila banding ditolak maka akan diberikan sanksi yang berat.

Bagi perusahaan sangat diperlukan tehnik pengelolaan resiko setelah dilakukan identifikasi resiko yang mungkin akan muncul sehingga bisa berdampak bagi tujuan yang ingin dicapai perusahaan. Adapun teknik mengelola resiko dapat dilakukan oleh perusahaan dengan cara sebegai berikut :

a. Penghindaran resiko. Penghindaran resiko dapat dilakukan dengan memperhatihan apakah kegiatan perusahaan akan berdampak sosial yang terlalu besar bagi perusahaan. Memperhatikan peraturan yang ada apakah peraturan tersebut kondusif dengan kegiatan usaha kita, dan juga harus memperhatikan apakah total resiko di atas ambang batas yang telah ditetapkan oleh perusahaan. Perusahaan tidak mengambil tindakan yang dapat memicu terjadinya resiko tertentu merupakan cara penghindaran resiko, contohnya seperti meminta restitusi.

b. Pengurangan resiko. Pengurangan resiko dilakukan dengan cara menghindari penyebab munculnya resiko serta mengambil beberapa tindakan yang dapat memberikan resiko serta dapat menghilang secara alamiah. Perusahaan bisa melakukan Pengurangan pajak yang dapat dilakukan dengan menghindari penyebab timbulnya resiko.

c. Pencegahan resiko. Melakukan pencegahan penyebab terjadinya resiko dan mengusahakan meminimalisasi kerugian seandainya resiko tersebut benar terjadi menimbulkan Sprinkler system (menyebarkan), Stop-loss order 
d. Pemindahan Resiko. Dengan mempekerjakan pegawai yang kompeten serta memiliki loyalitas, integritas dan kapabilitas akan menghasilkan pegawai yang ideal untuk bekerja dalam perusahaan atau mempekerjakan konsultan pajak secara terbuka atau tertutup, dimana konsultan pajak dapat menjadi creative accounting penusahaan apabila terjadi sangketa pajak, maka konsultan pajak yang terbukalah yang mendapat pelimpahan kuasa dari perusahaan dan sekaligus menjadi pelindung hukum atau Undang-undang bagi perusahaan merupakan cara pemindahan resiko yang bisa dilakukan oleh perusahaan

e. Penanganan Resiko. Penanganan resiko ini dapat dilakukan perusahaan dengan melakukan penanganan resiko yang sudah terencana, menangani atau menanggung risiko berdasarkan profil cost-benefit dan juga perlu penanganan resiko yang tidak direncanakan akibat dari ketidakmampuan dalam mengidentifikasi resiko.

\section{Simpulan}

Resiko pada dasarnya merupakan suatu keputusan dan situasi yang di ambil sehingga dapat menimbullkan akibat yang negatif bagi perusahaan. Tujuan tunggal dari Manajemen Resiko yaitu dalam hal menekan resiko yang dapat bermanfaat dalam hal memberikan informasi dan perspektif kepada manajemen tentang semua profil resiko serta adanya perubahan mendasar mengenai produk dan pasar, dan diperlukannya lingkungan bisnis dan perubahan dalam proses manajemen resiko. Manfaat lain manajemen resiko ini yaitu untuk menyampaikan isu sentral tentang formulasi kebijakan manajemen resiko dan review-nya, menghitung dan mengukur besarnya risk exposure, serta mampu menetapkan alokasi sumber-sumber dana sekaligus limit resiko dengan lebih tepat untuk bisa menghindari konsentrasi portofolio yang berlebihan serta dapat membuat cadangan yang memadai untuk mengantisipasi resiko yang sudah diukur dan dihitung serta mampu menghindari potensi kerugian yang relatif lebih besar. Beberapa tahapan pengendalian resiko yaitu mulai dari penetapan konteks, identifikasi resiko, analisis resiko, evaluasi resiko, penanganan resiko, review / monitoring, konsultasi dan komunikasi. Sedangkan tujuan dari manajemen pajak yaitu menerapkan peraturan perpajakan secara benar dan usaha efisiensi untuk mencapai laba dan likuidatas yang seharusnya, dengan cara melaksanakan fungsi perencanaan pajak, pelaksanaan kewajiban pajak, dan pengendalian pajak. dikarenakan terdapat resiko-resiko pajak yaitu adanya resiko PPh PPN, risiko PPh Badan, resiko PPh 21, resiko Pemotongan / Pemungutan oleh pihak ketiga. Oleh karena itu, manajemen resiko pajak penting dilakukan oleh setiap perusahaan, agar setiap perusahaan dapat mengelola resiko pajak dengan baik dan dapat mengurangi dampak negatif dari resiko yang dialami perusahaan. Dalam memenuhi kewajiban pajak, perusahaan perlu melakukan pemotongan atau pemungutan, penyetoran dan pelaporan, namun harus mengikuti peraturan perpajakan yang berlaku, apabila adanya pelanggaran maka sanksi perpajakan bisa dijatuhkan kepada perusahaan yang terkait, oleh karena itu manajemen resiko perpajakan sangat penting dilakukan oleh perusahaan dengan baik untuk menghindari sanksi.

\section{Daftar Pustaka.}

Bernard Sinaga, 2011. Pengaruh Karakteristik Corporate Governance, Kompensasi terhadap Manajemen Pajak. Jurnal Akunransi dan Keuangan. Vol.11 No.1, Mei 2009:30-41.

Chairil Anwar Pohan, 2015. Manajemen perpajakan. Edisi Revisi, PT Gramedia Pustaka Utama, Jakarta.

Hutagaol, John, Darussalam dan Danny Sepriadi. 2006. Kapita Selekta perpajakan. Salemba Empat, Jakarta.

Irham Fahmi, 2010. Manajemen resiko. Bandung: Alfabeta

Jones, Sally M. 2014. Principles of Taxation for Business and Invesment Planning. Irwin Mc Graw Hill.

Ketentuan Umum dan Tata Cara Perpajakan sebagaimana telah beberapa kali diubah terakhir dengan Undang-Undang Nomor 16 tahun 2009.

Michel Crouhy, Robert Mark, Dan Galai (2000) Risk Management. McGraw-Hill Education.

Muljono, Djoko. 2008. Ketentuan Umum Perpajakan. Penerbit Andi, Yogyakarta.

Peraturan Menteri Keuangan republic Indonesia nomor 191/PMK.09/2008

Peraturan Menteri Keuangan republic Indonesia nomor 142/PMK.010/2009

Suandy, Erly. 2008. Perencanaan pajak. salemba Empat, Jakarta

Sukardi, 2013. Metodologi Penelitian Kompetensi dan Praktiknya. Jakarta: PT. Bumi Aksara.

Surat Edaran BI No 5/21/DPNP, 2003. Penerapan manajemen resiko bagi bank Umum

Undang-Undang Republik Indonesia Nomor 7 Tahun 2004 tentang Perdagangan.

Undang-Undang Nomor 7 Tahun 1983 sebagaimana telah beberapa kali diubah terakhir dengan Undang-Undang Nomor 36 Tahun 2008 tentang Pajak Penghasilan.

V. Wiratna Sujarweni, 2014. Metodologi Peneltian. Yogyakarta: Pustaka Baru Press.

Zain, Mohammad. 2007. Manajemen Perpajakan, Edisi 3. Salemba Empat, Jakarta. 